\title{
Active surveillance: an essential tool in safeguarding the health and well-being of children and youth
}

\section{Danielle Grenier MD}

Published at www.cmaj.ca on June 28, 2007.

$\infty$

See related article page $\mathrm{I} 6 \mathrm{I}$

I $\mathrm{n}$ this issue, Ward and colleagues ${ }^{1}$ report the findings of their study of the incidence of vitamin D-deficiency rickets in Canada. Through the Canadian Paediatric Surveillance Program, they identified Io4 confirmed cases of vitamin D-deficiency rickets among children up to 7 years of age, with an estimated annual incidence rate of 2.9 per 100 ooo children. These children presented with important clinical manifestations of rickets, such as skeletal deformities, hypocalcemic seizures, delayed developmental milestones and fractures.

As Ward and colleagues note, vitamin D-deficiency rickets is not a new phenomenon, and it is preventable by the simple administration of oral vitamin D supplements. Their article raises many questions: Why is rickets still present in a country where food is abundant? Is a subset of the population at increased risk? How could prevention strategies be improved? Is it important to conduct surveillance of rickets? If so, should surveillance be conducted through the Canadian Paediatric Surveillance Program?

According to the United Nations' Convention on the Rights of the Child, ${ }^{2}$ children and youth have "the right to the enjoyment of the highest attainable standard of health and to facilities for the treatment of illness and rehabilitation of health." Health care providers have a duty not only to promote and to safeguard the health of their patients, but also to participate in ethical health research, including epidemiological research that will advance knowledge and guide treatment.

If a disease or condition is uncommon and data are sparse or nonexistent, investigators need a national system to identify cases in order to answer their research questions. The Canadian Paediatric Surveillance Program is a wellestablished active surveillance system, made strong by the participation of more than 2300 pediatricians and pediatric subspecialists who provide timely national non-nominal data (Figure I). This system has definite advantages over more traditional passive reporting systems. However, collection of data is only the initial step. The World Health Organization (WHO) defines surveillance as "the ongoing systematic collection, analysis and interpretation of data and dissemination of information to those who need to know in order that action be taken." ${ }^{3}$ In other words, information collected through surveillance should not sit on a shelf, but rather it should lead to changes in clinical practice and public health interventions that prevent diseases. In accordance with guidelines from WHO and the US Centers for Disease Control and Prevention for establishing a surveillance system, ${ }^{4}$ the Cana-

Box 1: Member countries of the International Network of Paediatric Surveillance Units
- Australia
- Netherlands
- Britain
- New Zealand
- Canada
- Papua New Guinea
- Germany
- Greece and Cypress
- Portugal
- Ireland
- Switzerland
- Latvia
- Trinidad and Tobago
- Malaysia

dian Paediatric Surveillance Program follows the " 3 Ds" of surveillance: detection, deduction and dissemination.

The Canadian Paediatric Surveillance Program Steering Committee (a governing body composed of multidisciplinary experts from public health, medical and legal fields) favours studies that have strong scientific and public health importance and those for which surveillance is the most appropriate way of collecting data. The program uses a 2-tiered reporting process to identify and investigate cases: an initial check-off form and a detailed follow-up questionnaire. The high mean monthly response rate $(82 \%)$ and completion rate of the follow-up questionnaire ( $93 \%$ ) reflect that the participants value the program and are committed to ongoing pediatric epidemiological research.

Thus far, 34 studies have been conducted through the Canadian Paediatric Surveillance Program on a range of infectious and vaccine-preventable diseases, genetic and metabolic conditions, childhood injuries and mental health disorders. ${ }^{5}$ The public health impact of studies supported by the program is described in Table I. For example, one study reported that, in $60 \%$ of cases of group A streptococcus-related necrotizing fasciitis, the patient had a documented history of varicella in the preceding month. This result supports the recommendations by the National Advisory Committee on Immunization for universal childhood immunization against varicella; ${ }^{6}$ and the surveillance program would be useful for monitoring the impact of this public health decision in a follow-up study. In addition, a study of lap-belt syndrome confirmed that inappropriately restrained

Danielle Grenier is with the Department of Pediatrics, University of Ottawa, and is Medical Affairs Officer, Canadian Paediatric Society, Ottawa, Ont. 
children injured in motor vehicle accidents have a high rate of permanent spinal cord lesions (25\%). ${ }^{7}$ This study has increased awareness and contributed to the Ontario Ministry of Transportation's decision to mandate the use of booster seats. Advocacy efforts will continue until all provinces and territories adopt both the use of proper child restraints in motor vehicles and booster-seat legislation.

As one of the founding members of the International Network of Paediatric Surveillance Units, which has 15 members (Box I), the Canadian Paediatric Surveillance Program offers the opportunity for international collaboration. ${ }^{8}$ Studies conducted in more than one country allow for international comparison of diseases and conditions (e.g., hemorrhagic disease of the newborn, ${ }^{9,10}$ congenital rubella syndrome, ${ }^{11}$ severe neonatal hyperbilirubinemia ${ }^{12}$ ) and other areas of public health (e.g., hemolytic uremic syndrome ${ }^{13}$ ). Countries such as Australia, Cyprus and Greece have initiated studies on vitamin D-deficiency rickets. Since these countries enjoy a much sunnier environment than Canada, comparison of the results from these studies with the Canadian data presented by Ward and colleagues will be most interesting.

The study by Ward and colleagues confirms the validity of the recommendations made by the Canadian Paediatric Society for vitamin D supplementation. ${ }^{14}$ It also demonstrates the need for heightened efforts by health care providers to ensure adequate vitamin $\mathrm{D}$ intake for pregnant and lactating women and breast-fed infants. Epidemiological data also show the need for educational materials aimed at the general public and for a review of prevention strategies that target high-risk groups.

\section{Key points}

- Children and youth have the right to benefit from ethical health research

- National case identification is necessary to answer research questions about high-impact, low-frequency diseases

- Surveillance provides valuable, timely epidemiological information for action

- Governments have a duty to provide ongoing core funding to national surveillance pediatric research

The Canadian Paediatric Surveillance Program is a versatile tool able to acquire timely epidemiological data and to stimulate simultaneous collaborative research on diseases and conditions that are associated with high disability, morbidity, mortality and economic cost to society. However, because the program is based on the voluntary participation of pediatricians and does not include family physicians, the resulting incidence and prevalence rates are probably conservative. Future challenges include maintaining high interest and participation and continuing dissemination (in collaboration with the Canadian Paediatric Society) of results with important medical and public health implications for use in policy development.

As illustrated by Ward and colleagues, children and youth have the right to benefit from nationally funded epidemiological research that can identify risk factors, monitor public health interventions, inform the development of new prevention

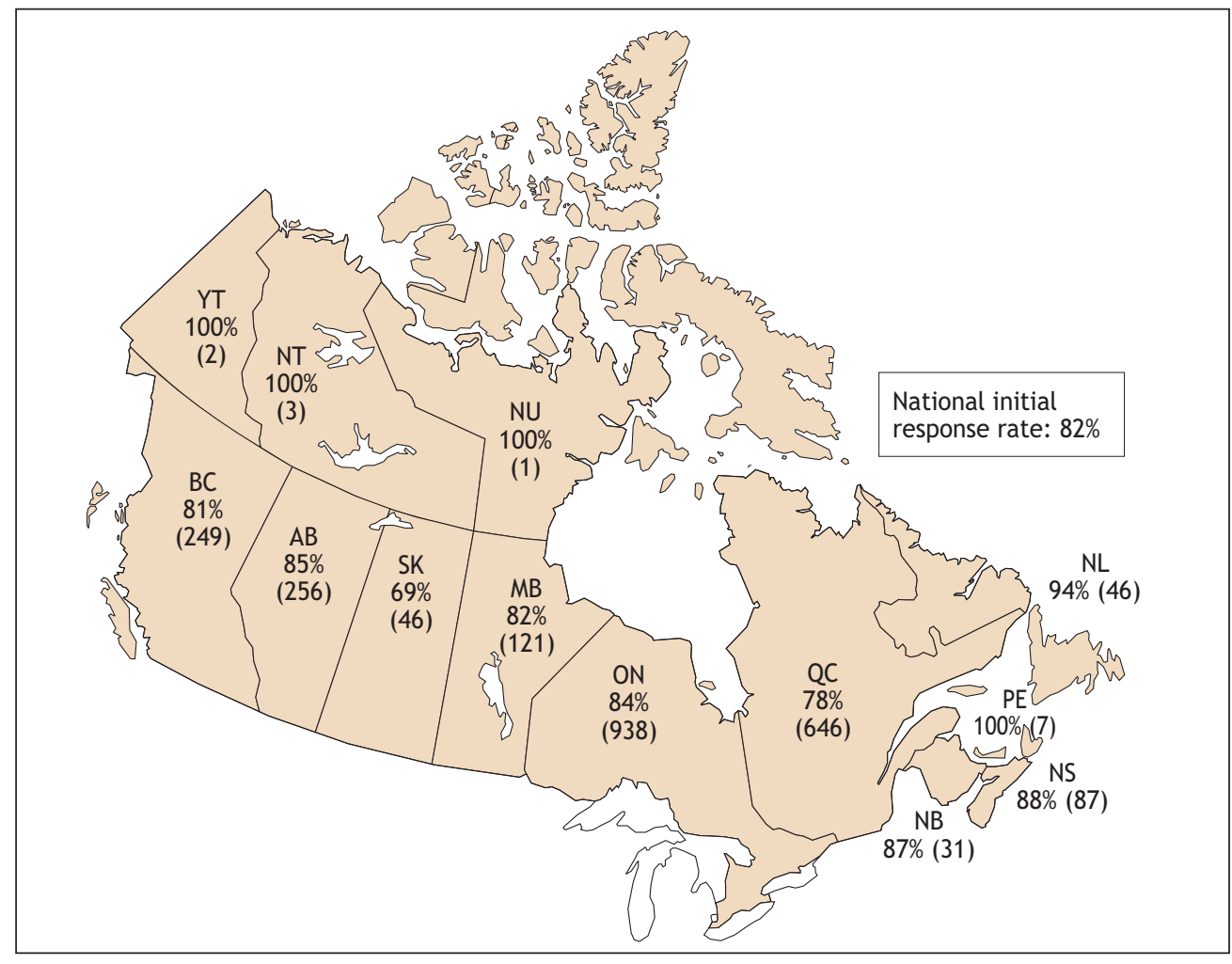

Figure 1: Initial response rates (and number of participants) in the Canadian Paediatric Surveillance Program in 2004. 
Table 1: Studies performed by the Canadian Paediatric Surveillance Program that have had an important public health impact

\begin{tabular}{|c|c|c|}
\hline Disease or condition & Main finding & Public health impact \\
\hline Necrotizing fasciitis & $\begin{array}{l}\text { Varicella was identified as the most } \\
\text { frequent risk factor among patients with } \\
\text { group A streptococcal-related necrotizing } \\
\text { fasciitis }\end{array}$ & $\begin{array}{l}\text { Supports the statement by the National } \\
\text { Advisory Committee on Immunization on } \\
\text { universal childhood immunization against } \\
\text { varicella }\end{array}$ \\
\hline Lap-belt syndrome & $\begin{array}{l}\text { - } 28 \text { cases identified in a } 2 \text {-year period; } \\
\text { paraplegia developed in } 25 \% \text { of cases }\end{array}$ & $\begin{array}{l}\text { Supports the advocacy by the Canadian } \\
\text { Paediatric Society that all provinces and } \\
\text { territories adopt the use of proper child } \\
\text { restraints in motor vehicles and booster-seat } \\
\text { legislation }\end{array}$ \\
\hline Congenital rubella syndrome & $\begin{array}{l}\text { Rare condition; } 10 \text { cases identified in a } 10 \text { - } \\
\text { year period, mostly in nonimmunized } \\
\text { women }\end{array}$ & $\begin{array}{l}\text { - Supports the need to maintain universal as } \\
\text { well as targeted immunizations }\end{array}$ \\
\hline $\begin{array}{l}\text { Subacute sclerosing } \\
\text { panencephalitis }\end{array}$ & $\begin{array}{l}\text { - Rare condition; } 2 \text { cases identified in a 4- } \\
\text { year period }\end{array}$ & $\begin{array}{l}\text { - Supports the need to maintain universal } \\
\text { immunization against measles and rubella }\end{array}$ \\
\hline $\begin{array}{l}\text { Hemorrhagic disease of the } \\
\text { newborn }\end{array}$ & $\begin{array}{l}\text { - Very low incidence: } 0.22 \text { per } 100000 \text { live } \\
\text { births }\end{array}$ & $\begin{array}{l}\text { Supports the Canadian Paediatric Society } \\
\text { statement that intramuscular vitamin K } \\
\text { injection is the "gold standard" for prevention } \\
\text { of hemorrhagic disease of the newborn }\end{array}$ \\
\hline $\begin{array}{l}\text { Neonatal herpes simplex virus } \\
\text { (HSV) infection }\end{array}$ & $\begin{array}{l}\text { Estimated incidence of } 5.9 \text { cases per } \\
100000 \text { live births; high mortality rate of } \\
15.5 \%\end{array}$ & $\begin{array}{l}\text { - Supports the need for a vaccine effective } \\
\text { against HSV-1 and HSV-2 }\end{array}$ \\
\hline $\begin{array}{l}\text { Neonatal severe } \\
\text { hyperbilirubinemia }\end{array}$ & $\begin{array}{l}258 \text { cases confirmed over a } 2 \text {-year period; } \\
\text { estimated incidence rate of } 1 \text { in } 2480 \text { live } \\
\text { births; } 72 \% \text { of the } 258 \text { cases were } \\
\text { readmitted at a mean age of } 5 \text { days }\end{array}$ & $\begin{array}{l}\text { Supports the statement by the Canadian } \\
\text { Paediatric Society that newborns should be } \\
\text { evaluated for risk factors of } \\
\text { hyperbilirubinemia and that bilirubin should } \\
\text { be measured before discharge }\end{array}$ \\
\hline
\end{tabular}

strategies and guide pediatric clinical practices. National surveillance is an essential tool contributing to the improvement of the health and well-being of children and youth.

Competing interests: None declared.

\section{REFERENCES}

I. Ward LM, Gaboury I, Ladhani M, et al. Vitamin D-deficiency rickets among children in Canada. CMAJ 2007; 177:16I-6.

2. Office of the High Commissioner for Human Rights, United Nations. Convention on the rights of the child. Article 24. Geneva: The Office;I99o. Available: www.un$\mathrm{hchr} . \mathrm{ch} / \mathrm{html} / \mathrm{menu} / \mathrm{b} / \mathrm{k} 2 \mathrm{crc}$.htm (accessed 2007 June I8).

3. World Health Organization (WHO). Making surveillance work. Geneva: WHO 200I. Available: www.who.int/vaccines-documents/DocsPDFor/www577.pdf (accessed 2007 June I8)

4. US Centers for Disease Control and Prevention. Updated guidelines for evaluating public health surveillance systems: recommendations from the Guidelines Working Group. MMWR 200I;50(RRI3):I-35. Available: www.cdc.gov/mmwr/preview/mmwrhtml/rr50rzar.htm (accessed 2007 June I8).

5. Canadian Paediatric Society. Canadian Paediatric Surveillance Program. Ottawa: The Society; 2007. Available: www.cps.ca/english/surveillance/CPSP/index.htm (accessed 2007 June I8).

6. Eneli I, Davies HD. Epidemiology and outcome of necrotizing fasciitis (NF) in children: a prospective surveillance study of the Canadian Paediatric Surveillance Program. J Pediatr. In press.
7. Canadian Paediatric Surveillance Program. Booster seat use: Better safe than sorry! Paediatr Child Health 2007;12:64. Available: www.pulsus.com/Paeds /I2_oI/Pdf/cpsp_ed.pdf (accessed 2007 June I9).

8. Elliott E, Nicoll A, Lynn R, et al. Rare disease surveillance: an international perspective. Paediatr Child Health 2001;6:251-60.

9. Canadian Paediatric Surveillance Program. Vitamin K injection — best prevention for newborns. Paediatr Child Health 2002;7:588-9. Available: hwww.cps.ca/English /surveillance/cpsp/publications/highlightspch.htm\#2002 (accessed 2007 June 2I).

ı. McMillan DD, Grenier D, Medaglia A. Canadian Paediatric Surveillance Program confirms low incidence of hemorrhagic disease of the newborn in Canada. Paediatr Child Health 2004;9:235-8.

II. Canadian Paediatric Surveillance Program. Congenital rubella syndrome - time to act on missed prevention opportunities. Paediatr Child Health 2003;8:107-8. Available: www.cps.ca/English/surveillance/cpsp/publications/highlightspch.htm \#Congenital\%2orubella\%2osyndrome (accessed 2007 June 2I).

I2. Sgro M, Campbell D, Shah V. Incidence and causes of severe neonatal hyperbilirubinemia in Canada. CMAJ 2006;175:587-90.

13. Grenier D, Elliott EJ, Zurynski Y, et al. Beyond counting cases: public health impacts of national Paediatric Surveillance Units. Arch Dis Child 2007;92:527-33.

I4. Godel J, First Nations and Inuit Health Committee. Vitamin D supplementation in northern Native communities. Paediatr Child Health 2002;7:459-63. Available: www.cps.ca/english/statements/II/iio2-02.htm (accessed 2007 June I9).

Correspondence to: Dr. Danielle Grenier, Medical Affairs Officer, Canadian Paediatric Society, 2305 St. Laurent Blvd., Ottawa ON KIG 4J8; danielleg@cps.ca 